BY

BARRINGTON MOORE

[Reprinted from Forestry Quarterly, Vol. XII, No. I, March, 1914.]

Press of

Watchman Printing House,

Bellefonte, $\mathrm{Pa}$. 



\section{FORESTRY IN AMERICA}

\section{AS REFLECTED IN PROCEEDINGS OF THE SOCIE'TY OF AMERICAN FORESTERS.}

\section{BY BARRINGTON MOORE.}

The object of the present review is threefold:

First, to show the trend of thought and progress of American forestry as reflected in the Proceedings of the Society of American Foresters. For this purpose the articles have been arranged under headings, in chronological order under each heading.

Second, to make more available for reference the material contained in the Proceedings of the Society of American Foresters, from the first number of Volume VII, number 2, inclusive.

Third, to give a general view of the field already covered, in order to show the degree of attention devoted to each subject.

\section{I-HISTORICAL.}

The Application and Possibilities of the Federal Forest Reserve Policy. By Edward T. Allen. Vol. I, No. 2.

$\mathrm{Mr}$. Allen's article is most interesting, throwing light on the administration of the Forest Reserves in the Land Office days. As he says, it was unfortunate that incompetent men, placed on the Reserves by political pull, antagonized the people by bad management.

The Disposal of Public Lands. By George W. Woodruff. Vol. I, No. 2.

This article has nothing to do with forestry, but is of interest to American foresters in that it gives an account of the development of the policy with regard to public lands, which gave rise to the present National Forests. Much stress is laid on the frauds practiced to secure public land.

Objections to the Forest Reserves in Northern California. By Albert F. Potter. Vol. I, No. 2.

Ten objections on the part of the people of Northern California are given to the creation of forest reserves. These objections have since disappeared; but they serve to show the opposition with which the reserves first met.

Sir Dietrich Brandis. By Gifford Pinchot. Vol. III, No. I. This is an enthusiastic appreciation of the forester who introduced the 
science into India, by the man who has done so much for forestry in America. It will serve as an inspiration to all American foresters.

Relation Between State and Private Forestry in Pennsylvania. By Joseph Trimble Rothrock. Vol. IV, No. I.

This deals with the relation of State forestry to the public, rather than with the relation between State and private forestry. It is full of details of the difficulties encountered by the forestry movement in Pennsylvania.

\section{II-GENERAL.}

Forestry and Foresters. By Theodore Roosevelt. Vol. I. No. I.

This is a general article showing the vital importance of forestry to the United States as a whole. As Mr. Roosevelt says, the keynote of forestry is and always should be the upbuilding and maintenance of prosperous homes.

Bibliography of Southern Appalachians. By Helen Stockbridge. Vol. VI, No. 2.

This is a compilation which will be of great value as a reference for those interested in the purchase of land for forest reserves in the White Mountains and Southern Appalachians.

\section{III-DESCRIPTIVE.}

\section{Deforestation in China. By Bailey Willis. Vol. I, No. 3 .}

The treeless condition of Northern China is strikingly shown. The forests of once densely covered mountain ranges have been destroyed to such an extent that the rich are "reduced to sticks one inch in diameter by eight inches long for firewood." The "saving clause," which does not save the forests but modifies the effect of their destruction, is the wonderful skill with which the Chinese terrace and cultivate the bare steep slopes.

Why Prairies are Treeless. By Alfred Gaskill. Vol. I, No. 3 .

Many facts are brought together tending to prove that prairies were caused by fire. These facts, though interesting, are not conclusive; and the argumentative tone pervading the article reacts upon the reader.

Some Philippine Forest Problems. By R. C. Bryant. Vol. II, No. I.

This article gives some of the difficulties encountered in introducing forestry into the Philippines, difficulties naturally attendant upon studying tropical forests containing vast numbers of unidentified species whose growth and silvical characteristics cannot be investigated by methods used in temperate regions. Great as are the difficulties which Mr. Bryant brings out, he does not touch upon the greatest obstacle of all, namely, the system of Caingins, or shifting, cultivation by which large areas of virgin forests are annually destroyed for the sake of two or three years' miser- 
able cultivation. Native hostility is also a serious drawback. For further information on the Philippine forests, see article by $\mathrm{H}$. N. Whitford in Vol. VI, No. I.

Some Forest Problems in Hawaii. By Ralph S. Hosmer. Vol. II, No. I.

An account of industrial conditions in the islands. The minor importance of forestry shows rather strikingly; but eventually there will be an opportunity for valuable silvical investigations. The main efforts must, just now, be directed toward protecting the forest land, most of which belongs to the government.

\section{Some Forest Problems of the Middle West. By Hugh P.} Baker. Vol. III, No. I.

This paper presents some of the problems of small farm forestry and advocates their solution. It is a general article of the propagandist type. Although containing little specific information, yet it undoubtedly served a very useful purpose.

Forest Resources and Problems of Canada. By B. E. Fernow. Vol. VII, No. 2.

This is an account of forest conditions in Canada. The first part of the paper is devoted to a description of the timber resources of Canada as known at present, and is illustrated by a map of forest regions. There is less timber, it occurs in more inaccessible regions, and is of poorer quality than in the United States. The second part gives an instructive and astonishng account of the Government's policv and methods with regard to the disposal of its timber.

State Forestry Problems. By A. F. Hawes, State Forester, Vermont. Vol. VII, No, 2.

The bulk of this article is devoted to questions which arise in fire protection, some of which apply to other eastern States. Protection from insects and animals (chiefly hedgehogs) is also discussed.

\section{IV-Silvics.}

Results of a Rocky Mountain Forest Fire, Studied Fifty Years After Its Occurrence. By W. J. Gardner. Vol. I, No. 2.

This is the first forestry article appearing in the Proceedings discussing actual forestry work on a specific problem; and it is perhaps significant that it should have been placed at the end of the number. The author gives his observations first in a general manner on the region, then on the influence of aspen, and on the restocking of the burn, followed by a few figures on the reproduction, growth, and tolerance of Engelmann Spruce. Though no particularly important results were obtained, still this is a distinct beginning. 


\section{Principles Involved in Determining Forest Types By Raphael} Zon. Vol. I, No. 3.

This is one of the first purely scientific articles appearing in the Proceedings, and one of the best. The author shows the scientific spirit in reaching after fundamental principles. He states very truly that physical factors are the causes of forest types. He makes one omission in that he fails to point out the importance of certain temporary types in forest management. An example of such a temporary type would be Douglas fir on the Pacific Coast; in this case the forester should not "endeavor to obtain in the shortest possible time the original forest type." Aside from this slight and natural omission, the principles laid down are those generally recognized by foresters to-day.

Objects and Methods of Eistablishing Permanent Sample Plots. By W. D. Sterrett. Vol. II, No. I.

Brief and instructive details of the objects and methods of establishing permanent sample plots are given. The article is strictly preliminary; and the objects given are therefore general. Some work has been done, but no results as yet obtained. This work has since been more highly developed at the Coconino (now Fort Valley) Experiment Station near Flagstaff, Arizona. However, the article shows the beginnings of careful experimentation.

A New Explanation of the Tolerance and Intolerance of Trees. By Raphael Zon. Vol. II, No. I.

The author begins with a thorough analysis of the factors affecting transpiration. He proves that on dry soils the influence of moisture is greater than that of light. Then follows account of experiments demonstrating that tree roots dry the soil. This is true enough, but does not bring out the comparative influence of light and moisture on tree growth, and this, after all, is the point, and one which it will be extremely difficult to solve considering the complex inter-relation and inter-action of the two factors.

His statement that the lack of reproduction under old trees is not due to lack of light but to lack of moisture is too strong; it might be that with the same small amount of moisture but with light, seedlings would grow. Something might be learned by experiments which would give seedlings the same amount of moisture as that found in the places under the trees where reproduction fails, but which would also give them full light. It would seem that Zon's first enthusiasm for this discovery carries him as far in the moisture theory as Pfeil was carried in the light theory. For Zon's maturer judgment see his and Graves' bulletin "Light in Relation to Tree Growth," Forest Service bulletin No. 92.

\section{Some Further Considerations Regarding the Tolerance and} Intolerance of Shade. By Herbert A. Smith. Vol. III, No. I.

Mr. Smith speaks a word of caution against being carried too far by Mr. Zon's enthusiasm for the new discoveries of the effect of moisture on tolerance.

Silvical Notes on Lodgepole Pine. By E. R. Hodson. Vol. III, No. I.

This paper gives some very interesting and important facts which were hitherto unknown, and draws logical conclusions about the reproduction 
of lodgepole pine. The discovery that too dense a stocking was injurious and that about 8,000 seedlings per acre constitute an optimum full stocking is well worth knowing. Some of his other facts are equally useful.

\section{Experiment Stations in Connection With the National Forests.} By S. T. Dana. Vol. IV, No. I.

The author shows the far reaching significance of the new (this was in I909) plans of establishing experiment stations on the National Forests, and touches upon some of the problems requiring solution. The establishment of these stations is probably the most important step taken by the Forest Service in placing the profession on a firm foundation. The value of the information which these stations will some day secure cannot be over-estimated.

\section{A Study of the Reproductive Characteristics of Lodgepole} Pine. By Gordon E. Tower. Vol. IV, No. I.

The author gives basic facts concerning the reproduction of lodgepole pine. Reproduction of this species is "not always so readily secured as was at first supposed." He discovered two forms: (I) that occurring on lime soils with cones difficult to open; and (2) that occurring on silica soils with cones opening readily. He also gives data on the effect of heat and of age of the seed on the power of germination.

\section{Economic Possibilities of Pinus Sabiana. By Charles H.} Shinn. Vol. VI, No. I.

This article belongs under Utilization as well as under Silvics, but was placed here because a large part of it is devoted to a description of the silvical characteristics of this tree. Mr. Shinn calls attention to this little known but abundant tree and gives valuable information concerning its characteristics and uses.

Efficacy of Goats in Clearing Brush Lands in the Northwest. By Charles S. Judd. Vol. VI, No. I.

This article gives a novel if not always practicable means of clearing brush lands. The use of goats is probably cheaper than clearing by hand and as effective if the object is reforestation.

Basket Willow Culture in Germany. By C. D. Mell. Vol V, No. I.

This is a specific article giving some interesting facts, but not all the facts. He does not say how long it takes to grow basket willow or how much it costs.

Chaparral Areas on the Siskiyou National Forest. By H. E. Haefner. Vol. VII, No. I.

This article contains interesting information about the brush fields of Southwestern Oregon, and silvical notes on the occurrence of the different types on the different geological formations. The point that the brush 
areas were deforested by fire is well taken. It would be worth while to impress that fact upon the settlers. His information about the natural restocking of the brush areas is too vague. We should like to know just what effect the brush has upon reproduction, whether it really aids reproduction by preserving soil moisture or is an unmitigated evil; what effect it has upon the reproduction of the different species, that is, whether or not a stand formerly composed of pine will be changed to one of a more tolerant species which can come up through the brush; what species first comes in; and the period required for natural restocking under different conditions. His recommendation about reforesting the most favorable sites first is good.

\section{Inier-relation Between Brush and Tree Growth of the Crater} National Forest, Oregon. By Harold D. Foster. Vol. VII, No. 2.

The author has brought together a number of interesting observations on the distribution, classification, and causes of brush; also its relation to reproduction. These observations tend to show that brush is caused by thinning of the stand due to fire. Brush keeps the soil in condition for reproduction but, he says, injures as much as it aids the reproduction. On this point there is room for argument; in the northern Sierras brush is the forerunner of a second forest. His attempts to find means of eradicating the brush show the impossibility of doing so except by shading.

Sitka Spruce of Alaska. By Bruce E. Hoffman. Vol. VII, No. 2.

This article contains silvical observations, chiefly on the occurrence, form and reproduction of Sitka spruce; illuminating details of the lumber industry in the vicinity of the Tongass National Forest; and definite recommendations for reconnaissance, timber sales and methods of cutting. At the end is a volume table based on diameter and average merchantable length. It is the first detailed information of the tree and region published. The article is an example of the manner in which American foresters grapple with a new problem.

\section{V-ECOLOGY.}

Plant Formations and Forest Types. By F. E. Clements. Vol. IV, No. I.

Professor Clements does a marked service to the profession of forestry by applying the principles of ecology to forest types. In so doing he lays the foundation for a thoroughly scientific study of the relation of the forest to its habitat. The result is that he gives a more stable starting point from whence to attack the complex problem of determining forest types. The article is indispensable for a proper understanding of forest types.

The Relation of Soil Acidity to Plant Societies. By Arthur W. Sampson. Vol. VII, No. I.

This article is of interest not only to ecologists but to foresters. The author has investigated in a scientific manner the effect of soil acidity and of alkalinity upon the occurrence of plant societies. His discoveries re- 
fute the theory maintained by certain scientists that the physical texture and moisture of the soil are of more importance than the chemical content. It is interesting to note that his study on the Manti National Forest showed that most of the tree genera found there prefer acid soils. He should, however, have stated the depth at which these tests were made, since forest soils are liable to be acid on the surface, but may be alkaline where the tree roots penetrate. These investigations are an important step in determining the fundamental physical factors which form the basis of forest types and on which Mr. Zon lays so much stress in his article "Principles Involved in Determining Forest Types," in Volume I, No. 3.

\section{VI-SiLVICULTURE}

Silviculture Applied to Virgin Forest Conditions. By Alfred Gaskill. Vol. I, No. 2.

This article is a plea for getting down to principles in silviculture rather than blindly following European text books. Hence it is advice rather than an exposition or study of a specific silvicultural problem. But the advice is excellent and has since been followed.

\section{A Rough System of Management for Reserve Lands in the} Western Sierras. By W: B. Greeley. Vol. II, No. I.

This is the best article on silviculture which has appeared in the Proceedings to date. It gives in a nutshell the essential features of the region in question and the leading silvical characteristics of the forest. From these the author evolves a thoroughly sound and practical system of silviculture. It is the work of a clear trained mind applying its training in a practical way. It marks the beginning of the true American Silviculture.

\section{The Silvicultural Results of Marking Timber in National} Forests. By Edward E. Carter. Vol. III, No. I.

The author gives in a very interesting manner the growth of systems of marking in the important forest regions of the west. Early mistakes are shown as well as some of the difficulties encountered and imperfections in the methods used at the time the paper was delivered. The author's one oversight is that he emphasizes the value of the information which technical men can give the rangers without bringing out the fact that the technical man must. have a thorough acquaintance with the forest before his advice can carry weight or even be worth following.

\section{Condition of American Silviculture. By Henry S. Graves.} Vol. III, No. I.

Mr. Graves shows how little actual practice American foresters have had and how little is known about the fundamental American silvical conditions necessary for developing proper silvicultural methods. He emphasizes the necessity of having a definite silvicultural aim: not to forget what is desired and expected of the forest in the future, but at the same time, we must not become disappointed at failures. Finally he emphasizes one of the most important truths in forestry, the necessity of knowing principles rather than systems. 
Some Notes on the Yellow Pine Forests of Alabama. By R. C. Bryant. Vol. IV, No. I.

The figures on the growth of longleaf pine and the facts concerning lumbering clearly show the impossibility of forestry for private owners of longleaf pine land. Thorough silvical studies would apparently be useless since there is no government land in Alabama on which the findings could be applied, and conditions in Florida are somewhat different. The silvicultural systems suggested are interesting, but would carry more weight if based on more silvical facts.

\section{The Selection System. By Henry S. Graves. Vol. V, No. I.}

In this article $\mathrm{Mr}$. Graves brings together much useful information about the system of silviculture with which he has had much experience. It is the system he recommended in his Adirondack Working Plan. The last part of the article is particularly interesting, for he refers to the modification of the selection system known as the "group selection system" and now widely applied on National Forests bearing uneven aged stands.

Management of Loblolly and Shortleaf Pines. By W. W. Ashe. Vol. V, No. I.

The author combines scientific information and practical application to a marked degree. He gives specific and fairly detailed information of considerable importance. The management, though a little crude, is probably as good as conditions will allow. The article loses by poor presentation some of the force which it otherwise would have.

Strip Thinnings. By Theodore S. Woolsey, Jr. Vol. VI. No. I.

The author gives a method of thinning dense second growth spruce and balsam stands in the northeast. The method is adapted only to certain infrequent conditions and will probably not be widely used.

\section{Results of Cuttings on the Minnesota National Forest Under} the Morris Act of I9.02. By Raphael Zon. Vol. VII, No. I.

Mr. Zon's observations indicate very poor silvicultural results from the cuttings under the Morris act. The seed trees left are wholly inadequate, cutting was done in poor seed years, and the areas have grown up with such rank vegetation as to prevent further reproduction, particularly of white pine. His recommendation about clearing off the brush with fire at the time of cutting is of great interest, but should be most thoroughly tried out before being put into practice.

Silvicultural Systems of Management for Central Rocky Mountain Forests. "By Carlos G. Bates. Vol. VII, No. I.

The author gives an interesting sketch of the determining silvical conditions on each of the important Rocky Mountain types as far as these conditions were known at the time of writing. On this basis he builds 
up sound logical methods of silviculture, harmonized on the one side with the interests of the forest and on the other with those of lumbermen. Since the article was written lodgepole pine has been found to be far less intolerant than had been commonly supposed. This would make possible the application of the selection system which the author rejects, but would not prevent the use of the group selection system which he advocates.

Border Cuttings: A Suggested Department in American Silviculture. By A. B. Recknagel. Vol. VII, No. 2.

A detailed description of an European method of silviculture applicable only in accessible regions where intensive forestry is possible. Although not practicable for America's present day conditions, the method is worth knowing about for future reference.

Silvicultural Systems for Western Yellow Pine. By Earle H. Clapp. Vol. VII, No. 2.

This valuable paper brings together all the silvicultural information gathered by the Forest Service concerning western yellow pine. It reconciles the two opposing methods of handling the tree, the shelterwood method, and the group selection. Mr. Clapp shows that the latter is applicable to all but unfavorable situations on which reproduction requires shelter. Here the shelterwood system is better for securing new reproduction. The difficulty is that under present logging conditions much of the stand-up to two-thirds of the volume - must be removed at the first cut, thus largely destroying the shelter. Furthermore the area cannot be cut again for from 30 to 50 years, by which time the reproduction will have been shaded out, or will be badly damaged by the removal of the remaining well distributed portion of the stand.

Natural versus Artificial Regeneration in the Douglas Fir Region of the Pacific Coast. By Thornton T. Munger. Vol. VII, No. 2 .

The author describes conditions in the Douglas fir region of the Pacific Coast, and gives the pros and cons of both methods of regeneration. He seems to be on the defensive throughout, and ends by saying that, except in four exceptional classes which he mentions above, "natural regeneration is practicable, reasonably sure of success, and as inexpensive as any method of artificial regeneration." Such opinions will, it is hoped, lead to thorough experiments to determine the applicability of both methods before the Service commits itself to either.

\section{VII-FORESTATION.}

Problems in Nursery Practice. By Clifford Robert Pettis. Vol. IV, No. I.

This paper forms a very valuable contribution to all work connected with forest nurseries. It gives in a clear manner the essential details of the author's experience in directing the work of the largest scientifically managed forest nursery in the United States. 
The Growing of Eucalypts. By Fred G. Plummer. Vol. V, No. I.

Here is what a man wants to know before planting Eucalyptus. It is a general article followed by eleven pages of bibliography of Eucalyptus, so will serve as an excellent reference for anyone wishing further information on these important trees.

E.rperiments in Sandhill Planting. By Carlos G. Bates. Vol. $\mathrm{V}$, No. I.

This article shows very distinct progress in forestry thought and practice. It is detailed, specific, and extremely instructive. The author gives a series of very interesting experiments which were made in such a way as to show how each factor acts and why. The effect of plant competition on the moisture supply is particularly interesting. The article is, therefore, pure forestry of great future value, not only for the sandhills of Nebraska, but for every other region, as suggesting lines of investigation to be followed anywhere.

\section{Hardy Catalpa; a Study of Conditions in Kansas Plantations.} By A. E. Oman. Vol. VI, No. I.

The author gives interesting and instructive details concerning the starting and care of hardy catalpa stands. He treats the subject in a careful and detailed manner, giving the causes of all the facts and recommendations he brings out. The article is therefore a valuable addition both to the forester's and farmer's knowledge of handling this valuable tree.

\section{Encalyptus Possibilities on the Coronado National Forest. By} R. L. Rogers. Vol. VI, No. I.

A thorough knowledge of conditions on the Coronado help to make Mr. Rogers' article of interest and value. He shows clearly that, although certain species of Eucalyptus can probably withstand the temperatures, it is doubtful if they could endure the drought unless previously established hy irrigation. His conclusion is the need for thorough experimentation. The article is written in a careful scientific spirit, and should be read by all foresters who have under consideration the planting of Eucalyptus in arid regions.

\section{Sced Production and How to Study It. By Raphael Zon and} C. R. Tillotson. Vol. VI, No. 2.

This article is the result of painstaking and scientific effort. In the first place the authors state the four problems involved. The mere statement of these problems is a stimulus to forestry research. The history of the study of seed production is given in detail from its beginning to the present time; presented last is Zon's and Tillotson's method of studying seed production, which, briefly, consists in determining the per acre production of seed for any given stand. The method is somewhat complex and the idea is not concurred in by all foresters (see discussion of this article in Vol. VII, No. I). Nevertheless the article has vigor and originality and marks a distinct step forward in the professional thought of the country. 
Seed Production and How to Study It: Discussion.* By S. T. Dana, Bristow Adams, and Raphael Zon. Vol. VII, No. I.

This paper is wholly different from any of the others, except $\mathrm{Mr}$. Herbert A. Smith's "Some Further Considerations Regarding Tolerance and Intolerance of Shade," in Vol. III, No. I, in that it is a discussion of an article which has already appeared in the Proceedings. Mr. Dana takes the position that Mr. Zon's sample-plot method of studying seed production is too complex and expensive; furthermore it is analogous to the use of yield tables in finding the volume of stands, and yield tables, he says, are of but little use in our irregular forests. His alternative would be to estimate the seed crop by single trees instead of by area, using a previously constructed "seed-volume-table," just. as a timber estimator uses a volume table of board contents.

Mr. Bristow Adams has no faith in either method of studying seed production and believes that there are other problems which are more in need of solution. He gives methods of increasing the seed crop of individual trees. 'Then follows Mr. Zon's reply to Mr. Dana and Mr. Dana's reply to Mr. Zon, at the end apparently neither being converted. The discussion serves to bring out the advantages and disadvantages of each method.

Forest Planting in Northern Michigan. By Willnam B. Piper. Vol. VII, No. 2.

This paper relates to the planting done by the Forest Service on the Michigan National Forest. The work has been almost wholly experimental; something of value has been learned, but much further experimentation will be necessary.

\section{VIII-MENSURATION.}

Timber Estimating. By Herman Haupt Chapman. Vol, IV, No. I.

Professor Chapman, and one or two other foresters in the country doubtless understand forest maps and timber estimating better than anyone else. The interest and value of this article is therefore obvious. It is a brief outline of some of the more important methods of timber estimating and of the principles underlying them. Timber estimating is of course the phase of the profession closest to the old timber cruisers, a work in which foresters, lacking the experience of the timber cruisers, have surpassed these formerly infallible men by the use of scientific methods.

A Method of Studying Growth and Yield of Longleaf Pine Applied in Tyler County, Texas. By Herman Haupt Chapman. Vol. IV, No. 2.

Of all the methods of studying yield devised by foresters, this is the most original and interesting. There can be no question that the method

* The original paper of the same name by Raphael Zon and C. R. Tillotson appeared in Vol. VI, No. 2. 
is thoroughly workable and productive of excellent results in longleaf and shortleaf pine; and also that it is equally applicable to western yellow pine. Furthermore there seems to be no reason why the method should not be used with any species which forms even aged groups. It is at present being tried by the Forest Service in the mixed conifer type (western yellow pine, sugar pine, incense cedar, Douglas fir and the white fir) of the western Sierras, and if successful will probably revolutionize the study of yield throughout the entire country.

The Standardizing of Log Measures. By Edwin Allen Ziegler. Vol. IV, No. 2.

This is a sound article showing clearly the variations caused by different $\log$ scales and methods of sawing, and advocating the use of the cubic foot. It is a specific article contributing something to professional knowledge and is also partly propagandist. There is no. doubt that the author's recommendations will eventually be adopted, but not for a long time or without a struggle. This should not, however, prevent foresters from keeping the end in view and making every effort to attain it.

\section{Forest Mapping and Timber Estimating as Developed in Mary-} land. By Fred W. Besley. Vol. IV, No. 2.

The work herein described is instructive in that it shows how to get a rough but sufficiently accurate idea of forest. areas and stands in a woodlot state. It will be of considerable value to those starting forestry for the first time in a state, and to foresters in states which have for some time applied the science.

\section{The Log Scale in Theory and Practice. By Harry D. Tieman.} Vol. V, No. I.

This article is the result of much original research in the important and complex subject of $\log$ measurement, in consequence the author is able to give in considerable detail the underlying principles of his subject. $\mathrm{He}$ has also evolved, as a result of the actual measurement and sawing out of 224 perfect logs, an ideal rule which he expresses by a formula. The article is a valuable contribution, not only to the scientific knowledge of the profession, but also to the practical application of this knowledge to the lumber industry.

\section{IX-ENGINEERING.}

\section{A System for Getting Topography in Reconnaissance Work in} the Western Cascades. By Walter H. Leve. Vol. VII, No. 2.

The article gives the details of the topographic part of the reconnaissance in the western Cascades of Washington. The nature of the subject, together with the none too clear style of the author, would make this paper difficult to understand for one without much topographic experience. Since the article will be read chiefly by men engaged in this work it will have value for starting discussion and suggesting improvements. One improvement would be to have the field man complete his sketch in the field rather than turn in a series of short contours. 


\section{X-MANAgement.}

Some Government Timber Sales in the Southwest from the Practical and Technical Standpoint. By Theodore S. Woolsey, Jr. Vol. II, No. I.

This paper gives an account of mistakes made in the earlier administration of timber sales. These mistakes, however, laid the foundation for the better administration of to-day.

\section{Managing a National Forest from the Business Standpoint.} By 'Theodore S. Woolsey, Jr. Vol. III, No. I.

This paper throws an interesting light on the administration of the National Forests in 1908, and contains valuable suggestions. For example: His point about salaries and corresponding efficiency is well taken; his suggestions about keeping track of a Forest Officer's work, and about cost keeping have since been put into effect; while his recommendation of a more conservative use of the "raw product" (timber) has, owing to the necessity for making sales in order to put the Service on a paying basis, not yet been followed. However, with proper silvicultural methods of timber marking, there is no danger of depleting the capital.

\section{The New Reconnaissance-Working Plans that Work. By} Arthur Bernard Recknagel. Vol. IV, No. I.

This article is full of details concerning the early attempts of the Forest Service to regulate the cut on the National Forests. These attempts produced valuable information, if small results in a timber sale policy. The author also gives the details of the method of reconnaissance used for securing working plan data in District 3. 'This method has since been applied on nearly all the Forests of the District, furnishing estimates sufficiently reliable for all practical purposes, and excellent topographic maps. The emphasis placed on mapping and estimating was, however, carried to such an extent that the silvicultural method of cutting was, until very recently, in danger of being overlooked. Although the author in his enthusiasm forgets that "working plans that work" cannot be built in a day, he, nevertheless, stirred up interest in this important line of forest activity.

Preliminary Forest Management in the Southruest. By Theodore S. Woolsey, Jr. Vol. IV, No. I.

Under the above title the author discusses the method of fixing stumpage rates, the timber sale policy, and the method of fixing the annual limitation to the cut. His statement that all the timber in the Southwest will be needed locally is, I believe, over conservative. The population of Arizona and New Mexico is small, and will probably not increase greatly since most of the available agricultural land is already occupied. Although half of the article is devoted to the discussion of stumpage rates, the only basis which the reader can discover for the all-important minimum rate is competition; and yet it is only in exceptional cases that more than one bid is received. The timber sale policy of reserving certain areas for free use or for small sales is wise, and constitutes the soundest part of this article. The method of limiting the annual cut is correct enough, but tends to give too sanguine an impression of conditions in the region. The author fails to point out that this limitation of the cut, however neces. 
sary, is at present purely ideal and an object to be striven for, not by any means an accomplished fact. Perhaps the trouble is that he is so intent upon giving the reader an idea of what has been done that he fails to portray the conditions to which his measures must be applied, and consequently the effectiveness of these measures. The foreigner reading this article would be left with an undeservedly high impression of our rate of progress.

Regulating the Ammal Cut of National Forests. By S. La Moore. Vol. V, No. I.

This article gives a remarkably clear and truthful picture of the conditions on which regulations of the cut on National Forests must depend. By its frank statements of facts it gives a basis for future progress.

\section{Working Plans for National Forests of the Pacific Northwest.} By Burt P. Kirkland. Vol. VI, No. I.

In this article are two valuable contributions to the profession. First, the author explains the principles involved in making working plans, illustrating these principles with his own working plan; second, he develops strong arguments for the making of working plans. In his ex planation of principles in the first part of the article he effectually destroys certain fallacies, notably the one about elastic working circles composed of any number of National Forests.

His working plan is built on the area method with a volume check. It is a sound, intensely interesting and instructive piece of work with which every forester who deals with even aged stands should be familiar. His reasons for bringing the Forests up to thcir full productive capacity are logical, but he ignores the danger of overproduction in the lumber market which such a course would involve. (See article by W. B. Greeley, "National Forest Sales on the Pacific Coast," in Vol. VII, No. I). His arguments for the making of working plans are, on the whole, thoroughly sound, and should stir up those foresters who wait until the need for working plans arrives before making them. The making of a working plan is a matter of years, not of months; it is never too soon to begin collecting the data. Mr. Kirkland's article is, on the whole, one of the most thorough, detailed and specific articles, dealing with the science of pure forestry, which has ever appeared in the Proceedings. It is indispensable for reference.

The Essentials in Working Plans for National Forests. By Barrington Moore. Vol. VI, No. 2.

Methods for Regulating the Cut on National Forests. By Barrington Moore. Vol. VII, No. I.

XI-UtilizATION.

Influence of Lumbering on Forestry. By Austin Cary. Vol. III, No. I.

This is a sound, practical paper. The author shows how foresters fail to affect the management of lumbering concerns. This he attributes to the foresters' inability to see a proposition from the business standpoint. 
He also points out the increasing opportunities for the practice of forestry, chief among which are the large wood-using industries, such as pulp mills, which need permanent supplies of raw material, and permanent resident ownership. The keynote of the paper is the need for a proper balance between the technical and business management. The author must have the satisfaction of seeing that his principles are now recognized by the best foresters throughout the country.

\section{Shakes and Shake-making in a California Forest. By Charles} Howard Shinn. Vol. IV, No. 2.

This article is a complete and detailed account. of shakes and shakemaking from the earliest times to the present. It is in the nature of a memorial and defense of that picturesque but rapidly disappearing industry. Interesting figures are given comparing the value of the same class of material worked into shakes and sawn by a small portable mill.

\section{Wood Preservation-A Determining Factor in Forest Manage-} ment. By Howard Frederick Weiss. Vol. IV, No. 2.

The author points out the importance of wood preservation in determining the composition of future forests, in increasing the value of thinnings, in giving value to top logs hitherto a loss in lumbering, and in accelerating the removal of dead material. He builds up a strong, but, it must be admitted, rather one-sided, argument in favor of wood preservation.

Notes on Management of Redwood Lands. By Swift Berry. Vol. VI, No. I.

Mr. Berry has given us a brief, yet complete and clear account of the utilization of redwood. This is followed by notes on the disposal of cleared redwood lands and suggestions for keeping certain of these lands permanently in forest.

Conservation and Chemical Pulp. By Dr. B. Herstein. Vol. VI, No. 2.

The author gives a method of solving the hitherto vexing problem of disposing of the injurious waste from the sulphite process of pulp making. The method, now successfully used in Sweden, not only effectually does away with the damage from the waste, but yields a commercially valuable by-product, alcohol.

\section{XII--PROTECTION.}

Better Methods of Fire Control. By W. B. Greeley. Vol. VI, No. 2.

This article gives the most clearly thought out methods of preparing against and of handling difficult fire situations. It will, of course, be remembered that Mr. Greeley was in charge of the District on which the great fires of I9io occurred. The value of this article is such that the Forest Service had it reprinted and sent to every Forest Officer in the Service. 
Fire Problem on the Florida National Forest. By I. F. Eldredge. Vol. VI, No. 2.

The author gives a striking picture of the conditions on the Florida National Forest, and shows the impossibility of protecting the entire Forest. He gives an alternate scheme for concentrating fire protection on turpentined areas. The article is extremely instructive, particularly for those unfamiliar with Southern conditions, and who would advocate indiscriminate fire protection.

\section{XIII-FOREST INFLUENCES.}

Chaparral as a Watershed Cover in Southern California. By L. C. Miller. Vol. I, No. 3 .

This article is a study of chaparral itself rather than of the value of chaparral as a watershed cover. The latter fact is assumed as established, and the writer proceeds with his facts about the density of chaparral on different slopes, and methods to retain and increase the cover. If his premise be granted his article is an excellent plea for fire protection in the chaparral covered watersheds of important streams.

Striking Features of the Water Situation in California. By E. A. Sterling. Vol. II, No. I.

The author gives a clear and interesting account of the water situation in California, showing the vital importance of water, and the public understanding of the needs of the case. The article is, however, not scientific in that it does not show what infuence the forests have. It is primarily of importance for its relation to forestry.

Relation of Surface Conditions to Streamflow. By William L. Hall and Hu. Maxwell. Vol. IV, No. 2.

This is a strong article. It is logical, sound, impartial and scientific. The point that increased runoff causes decreased evaporation and consequently decreased precipitation is excellent.

Forests and Streamflow-An Experimental Study. By Carlos G. Bates. Vol. VI, No. I.

This article gives full details of the starting by the Weather Bureau in co-operation with the Forest Service of the most complete experiment which has ever been undertaken to determine the influence of forests on streamflow. Two forested watersheds of as similar character as possible have been selected. For a period of years all factors will be measured on each watershed, just as they now are, in order to obtain an accurate comparison of the two. Then one watershed will be deriuded and the other left forested. The effect will be accurately noted and cannot fail to yield the most accurate and convincing results.

\section{XIV-ECONOMICS.}

How Shall Forests be Tared? By Alfred Gaskill. Vol. I, No. 3 .

This article is an exposé of the important principles of forest taxa- 
tion, showing the injustice of the methods of taxation commonly used at present. It is also an attempt to adapt a complex problem to a crude and difficult situation. It shows that we must build up our own Forest Economics.

\section{Forest Fire Insurance in Germany. By Samuel J. Record.} Vol. II, No. I.

Mr Record gives a brief and interesting outline of the methods of fire insurance used in Germany, showing that the calculation is based on one of three methods of valuation, either on the cost value of the stand, on the forest expectation value, or on sale value; and that the rate increases with fire danger of the stand. The article gives a glimpse ahead at very intensive forestry which probably will not be applied in the United States for a number of years, but is none the less worth knowing about.

\section{Forestry for Railroads. By E. A. Sterling. Vol. IV, No. I.}

Mr. Sterling touches very closely the relation of the profession of forestry to the industrial world. The reason why the railroad has not taken up forestry is that foresters have failed to show railroad men forestry from a business standpoint. The importance of forestry to railroads lies not in planting, but in the management of timber lands.

The article is extremely interesting and instructive, but of necessity too vague. Mr. Sterling does not know enough about railroading, nor does any other forester. This ionorance is the vital trouble with the profession generally, for, unless forestry becomes an integral part of the business life of the country and answers its needs it can never be of any real value to the nation. The Service must graduate to where it feels ashamed of being unable to answer the questions which the railroad puts to it, and which Mr. Sterling so clearly enumerates. Most certainly, as he says, the Forest Service should uphold the railroad in the ownership of timberlands and in the disposal of minor products.

\section{National Forest Sales on the Pacific Coast. By W. B. Greeley.} Vol. VII, No. I.

This article shows clearly the underlying economic and business principles which should and actually do guide the Forest Service in handling the problem of timber sales. The principles are broad, sound and thoroughly practical and justly a deviation from the strict silvicultural requirements. The article is the result of clear thinking.

Timber Bonds. By Edward A. Brainiff. Vol. VII, No. I.

This article contains a long and very detailed account of bonds issued by lumber companies on the security of their timber lands. The author goes into all the features of these issues, giving many warnings to the prospective investor, but leaving impressed upon his mind a very favorable opinion of timber bonds and a keen desire to secure some. The article is well written and the information imparted interesting, but its connection with forestry is too remote.

XV-LEGISLATION.

What are the Essentials of a State Fire Law? By E. A. Sterling. Vol. I, No. 3 .

This paper deals chiefly with the provisions of the California fire law, 
at that time before the State Legislature. It nevertheless shows clearly the essentials of any ideal State fire law, which are: first, the preven tion of fires; and second, adequate machinery for the execution of the law. Although the paper was written eight years ago, it is still well worth while reading and understanding, particularly for those engaged in State forestry.

\section{XVI-EDUCATION.}

Some Problems in Forest Education. By Henry S. Graves. Vol. II, No. I.

In this paper the author strikes the keynote of the policy which should and does prevail in the best forest schools of the country. It is the importance of a broad and thorough technical training. He shows that American foresters need a broader training than do foresters in Europe. He mentions the leading subjects and shows their bearing, pointing out especially the need of learning to do research work, and of an understanding of fundamental principles in order to build up the new profession. His proposal for giving a different kind of training for technical foresters and for lumberman and rangers is the answer to the cry, at that time very insistent, for a more practical training. In fact, the paper might be considered somewhat in the nature of a defense of the system of thorough technical training.

\section{XVII-BOTANY.}

The Catalpa Septum: A Factor in Distinguishing Hardy Catalpa. By William H. Lamb. Vol. VII, No. 1.

Mr. Lamb gives one dependable characteristic by which the two catalpas may readily be distinguished; in distinguishing two similar species one dependable character is worth any number of variable ones.

A Synopsis of the Red Firs. By William H. Lamb. Vol. VII, No. 2 .

The author describes and illustrates with plates a few characteristics of the leaf and bract of the three firs, Abies nobilis, Abies shastensis and Abies magnifica, which render possible the sure and easy distinguishing of these hitherto confusing species.

\section{XVIII-AUXILIARY SUbJects.}

solls.

Forests as Gatherers of Nitrogen. By Treadwell Cleveland, Jr. Vol. V, No. I.

The author of this paper relates in a manner which can be understood by the layman some interesting experiments proving that forests increase the nitrogen content of the soil. He also states the opposing theories of Boussingault and R. Hartig as to how this complex and little understood process is carried on. 


\section{FOREST PATHOLOGY.}

Parasitism of Phoradendron Juniperinum Libocedri Engelm. By E. P. Meincke. Vol. VII, No. I.

In this article the author gives with scientific precision the details of his study of this interesting and peculiar mistletoe. He discovered that this plant, when it reaches a high age, lives without green exterior organs, and concludes that from the beginning it normally abstracts not only water and inorganic salts from the incense cedar, but organic food as well. This conclusion, as he states, still needs anatomical proof.

\section{Use of Soil Fungicides to Prevent Damping-Off of Coniferous} Seedlings. By Carl Hartley. Vol. VII, No. I.

This article presents briefly the results of experiments at the Halsey nursery in the sandhills of Nebraska, aiming to check the loss caused by damping-off. Different acids were used in different strengths. The results with sulphuric acid were satisfactory, but of course can not be applied directly to other conditions. They, however, serve as a valuable suggestion for carrying on similar experiments elsewhere.

\section{WOOD TECHNOLOGY.}

The Philippines as a Source of General Construction Timber. By Dr. H. N. Whitford. Vol. VI, No. I.

The author gives a concise account of the commercially important timbers of the Philippines; showing where they are found, the stand per acre, and important technical qualities of each. He emphasizes the predominance of the Dipterocarp family of which the most important are the lavans, the apitongs, and the yacals. It is interesting to note that these forests, contrary to the popular idea, do not contain merely "hard, durable timbers, scattered and hard to extract," but large quantities of cheap construction timbers. (For further information on the Philippines see article by R. C. Bryant, Vol. II, No. I.)

History of the Investigation of Vessels in Wood. By C. D. Mell. Vol. VI, No. I.

This article is a history of the investigation of vessels in wood, beginning with Malpighi (I628-1694) to Von Mohl (I842), most space being devoted to Von Mohl. The article contains no original researches, but is a resume of the investigations of European scientists, and, as such, forms a useful contribution to this phase of wood technology.

GRAZING.

Grasing in the National Forests. By L. F. Kneipp. Vol. VII, No. 2.

This paper deals with relationship between the live stock industry and the National Forests, and the dependence of this industry upon the forage which the Forests contain. The effect of grazing on the Forests, and of forestry on grazing is mentioned, and the importance of not disturbing the grazing industry is emphasized. The great benefits which the live stock industry has received from regulation of the range by the Forest Service are barely touched upon. 
Range Improvements and Improved Methods of Handling Stock in National Forests. By J. T. Jardine. Vol. VII, No. 2.

Range management is one of the big problems of the Forest Service. Mr. Jardine gives clearly the main lines of work; first, the improvement of the forage crop, both through artificial reseeding (only practicable on imited areas) and through natural reseeding by allowing the grass to profuce seed before it is eaten, thus strengthening the plants, seeding the area, and utilizing the forage at the same time; second, the study and application of new methods of handling sheep, which both increase the carrying capacity of the range, and the value of the sheep; third, experiments to determine the effect of grazing on tree reproduction; fourth, a grazing reconnaissance, to map and collect notes on the grazing resources of the National Forests. The paper gives a glimpse of scientific grazing work.

\section{Translations.}

Translations, in that they are not original articles, and do not belong to American forestry are placed at the end. Since, however, they will be useful for reference, they are included.

A New Method of Planting. By Morris Kenzenik. Translated from the German by S. T. Dana and E. H. Frothingham. Vol. IV, No. 2.

This article is well worth while knowing about, and adds greatly to the American foresters' knowledge of planting.

\section{Experiments in the Preservation of Forest Seeds. By E.} Zederbauer. Translation by Max H. Foerster. Vol. VI, No. I.

This article gives the results of some important German experiments in preserving the germinating power of tree seed by different methods of storage. The important point is to check as far as possible respiration and transpiration. This is done by means of temperatures below centigrade, sufficient moisture, and, sometimes, by the exclusion of air without using such low temperature.

\section{ConClusion.}

The foregoing papers show the subjects to which the Society of American Foresters have given most attention. The strength of Silvics and Silviculture stand out particularly since these are subjects about which Americans must secure their own data and build up their own practice. Utilization has two strong articles which, it is hoped, are a sign of the connection which will eventually be estabiished between the profession and the lumber industry, - a connection necessary for the welfare of both.

The papers taken in chronological order do not show a perfect upward curve, some of the best papers appearing in the early numbers, yet the general progress is noticeable. American foresters are more and more devoting themselves to specific problems, rather than generalities. 
Forestry in America.

INDEX

\section{$\begin{array}{lll}\dot{0} & 0 & 0 \\ > & 0 \\ 0\end{array}$}

Alabama, yellow pine forests, .......... Appalachians, Southern bibliography, ......

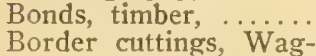
ner's method, ......

Brandis, Sir Dietrich. .

Brush and trees on Crater $\mathrm{Na}$ tional Forest, ....... " lands, use of goats in clearing, ..

Business management of National Forests,

California, water situation, ..............

Can a d a, forest resources and problems. ...........

Catalpa, distinction by septum, ....

Kansas plantations, .....

Central Rocky Mountain forests, silvicultural management... Chaparral on the Siskiyou $\mathrm{Na}$ $t$ i ona 1 Forest, watershed cover in Southern C a 1 ifornia,

Chemical pulp, source of alcohol,........

China, deforestation,..

Damping off prevention, ...........

Douglas fir, natural $z s$. artificial regeneration, ............

Ecology, forest types and plant formations, ...........

Education, problems,..

Fstimating timber, ...

Eucalyptus, growing of, possibilities in southern Arizona,
IV I 72

VI 2 I73

VII I 58

VII 2 I 45

III I 4

VII 2212

VI I 108

III I 4I

II I 20

VII 2 I 33

VII I 80

VI I 42

VII I 106

VII I 82

$$
\begin{array}{lll}
\text { I } & 3 & 147
\end{array}
$$

VI 2 I2n

I 3 I4I

VII I 96

VII 2 I87

IV I 50

II I 48

IV I II4

$V$ I 109

VI I 98

Experiment stations on

\section{National Forests, ..}

Fire control, better methods, .....

" insurance in Germany, .......

"problem on Fiorid a National Forest. ....... " results in Rocky Mountains,

Florida National Forest problem, ....... Forestry, generalization by Roosevelt,..

Forest influences, .... " reserves, $\ldots$...

reserves, objec-
tions to in northern $\mathrm{Cal}$ ifornia, ..... " reserve policy, a p p lication and possibilities, $\ldots \ldots \ldots$ types and plant f or m ations, ecological, . types, principles in determining, ........

Fungicides in soil, damping off prevention,

Grazing, $\quad$ i m p r o v ved " in Nationai

Forests, ... VII 2 I53

Hawaii, forest prob-

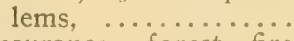
Insurance, forest fire in Germany, .......

Law, State fire, ......

Loblolly and shortleaf pine, management,..

Lodgepole pine, reproduction, pine, silvical notes, ...

Log scale in theory and practice, ...... Log scales, standardization, $\ldots \ldots \ldots \ldots$

Longleaf $\ddot{P}$ ine yield, Texas, ........... $\equiv z^{\circ}=$

IV I 22

VI 2 I 53

II I 95

VI 2165

I 2102

VI $2 \quad 166$

I 13

IV 2 I 33

VI I 53.3

I 270

I 24 I

IV I 50

I 3173

VII I $\infty 6$

VII 2160

II $1 \quad 29$

II I $n=$

I 3 I22

$V \quad I \quad S_{t}$

IV I $\&_{4}$

III I S2

T I 18

IV $2 \mathrm{I} / 2$

IV 2207 
Lumbering, influence on forestry, .......

Management, preliminarv in Southwest,..

Mapping and estimatin $\mathrm{g}, \mathrm{m}$ e thods in Maryland,

Marking timber, silvicultural results of,..

Michigan, planting experiments, .........

Middle West, forest problems, ..........

Minnesota $\mathrm{N}$ a $\mathrm{t}$ ion a 1 Forest, cuttings,....

National Forests-

business management,

(Minnesota) -

cuttings, ....... experiment stations, .........

(Florida) -

fire problem, .....

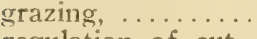
regulation of cut,

(Pacific Coast) sales of timber, .. working plans, ... (Pacific Coast, N.W.) -

working plans, ...

Nitrogen gathered by forests. ...........

Nursery practice, problems, ..............

Pennsylvania, St at e forestry and the public, ...........

$\mathrm{Ph}$ il ip pines, forest problems,

Philippines, source of construction timber.

Phoradendron juniperinum libocedri, parasitism, ..........

$P i c e a$ sitchensis of Alaska, ..........

Pinus contorta reproduction,

Pinus contorta silvical notes,

Pinus palustris of $\mathrm{Ala}$ bama, ...........

Pinus ponderosa, silvicultural systems, ...

Pinus sabiniana, economic possibilities, .

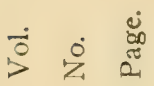

III I 67

IV I 107

IV 2106

III I I8

VII 2205

III I 90

VII I 100

III I 4I

VII I 100

IV I 22

VI 2 I66

VII 2 I53

$\mathrm{V}$ I IOI

VI I 42

VI 2 III

VI I I6

V I I3I

IV I 42

IV I 64

II I 3

- VI I 64

VII I 35

VII 2226

IV I 84

III I 82

IV I 72

VII 2168

VI I 68
Pinus taeda and Pinus echinata, man a $\mathrm{g} \mathrm{e}$ ment, ............

Planting, experiments in northern Michigan, ........... VII 2205

Planting, experiments in sandhills, ....... V I 59

Planting, new method, IV $222 \mathrm{I}$

Policy of forest rese rves, application and possibilities, ...

Prairies, why treeless,.

Public lands,

Pulp, chemical, source of alcohol, .........

Railroads, relation to forestry, ..........

Reconnaissance, new methods, ........... IV I I

Red firs, synopsis of,.. VII 2 I84

Redwood, management, VI I 104

Regulation of cutmethods of $\ldots . .$. VII I II on National Forests, .......... V I IOI

Sales of timberin Southwest, ...... National Forests of Pacific Coast, .... VII I 42

Sample plots, establishment, ..........

Sandhill planting experiments, ........ V I 59

Seeds, preservation of, VI I 92

Seed productiondiscussion, ........ VII I II7 study, ........... VI 2 I33

Selection system, .... V V I I

Sequoia sempervirens, management, ....... VI I 104

Shakes, making in California, ..........

Shortleaf and loblolly pine, management, .

Sierras, system of management, .......

Silviculture, American,

I, odgepole Pine, . . results of marking timber, virgin forests, ... I 262 
" $\begin{aligned} & \text { Western } \\ & \text { Yellow }\end{aligned}$

Sitka spruce of Alaska, VII $2 \quad 26$

Soil acidity, relation

to plants, ......... VII I 5 I

Southern Appalach-

ians, bibliography,

Southern yellow pine of Alabama, .......

State, forestry problems, ............ VII 2 I77

Streamflow, effect of surface conditions, .

Streamflow, forest in-

fluence experiment,.

Taxation of forests,..

Thinnings, strip, ..... VI I $_{38}$

Timber for construc-

$$
\text { tion, from }
$$

Philippines, VI I 64 sales, ....... II I II sales, ....... VII I 42 estimating, ... IV I II4 IV $\quad 2 \quad$ I33
Tolerance and intoler-

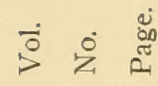

ance, new planation,

further considerations

Topography, getting in western Cascades,.. VII 2197

Virgin forests, silviculture, ........... Western yellow pine silvicultural systems, VII 2 I68

Willow for baskets in Germany, ..........

Wood, investigations in vessels of,. preservation, .. IV 2 I 85 essentials for $\mathrm{Na}$ tional Forests, ... National Forests on Pacific Northwest,

Yellow pine forests, Alabama, .......... IV I 72 Yield, longleaf pine in Texas, .......... IV 2207 


LIBRARY OF CONGRESS ||||||||||||||||||||||||||||||||||||||||||||||||||||||

00215299004 